\title{
BILIARY CIRRHOSIS
}

\author{
BY
}

\author{
P. R. EVANS, B.Sc., M.B., Ch.B., M.R.C.P.
}

(From the Children's Department, King's College Hospital, London)

Hepatic cirrhosis is conventionally classified, on a clinical basis, as syphilitic, portal, and biliary. On a pathological basis these types are described respectively as pericellular, multilobular and unilobular. Despite subdivision into further types the clinical classification is useful and valid. This is less true of the pathological terms used to describe the three varieties.

In congenital syphilis the fibrosis is diffuse throughout the liver and the term 'pericellular' cirrhosis is a correct description. In portal cirrhosis the islands of surviving liver tissue have lost their normal structure. They are not collections of well-defined lobules, and the condition is one of cirrhosis with nodular hyperplasia rather than multilobular cirrhosis. Biliary cirrhosis has received much attention since Hanot described it in 1876. Some authors have been sceptical of its existence, except as a consequence of obstruction of the common bile duct (Hutchison, 1936), whilst the pathological description of the fibrosis as unilobular has been criticized. Three of the cases reported here are examples of biliary cirrhosis, two of them with nodular hyperplasia. The fourth is an example of pure unilobular fibrosis with the clinical picture of portal cirrhosis.

As the pathology is uncertain, it is better to use a definition of biliary cirrhosis which rests upon clinical observation. Broadly speaking, the disease is a chronic affection of the liver, not caused by syphilis, in which jaundice occurs as an early sign, and is a prominent feature throughout the course, while evidence of portal obstruction appears late or not at all. Such a definition includes cases of chronic obstruction of the common bile duct with hepatic damage, and it is convenient to consider obstructive biliary cirrhosis first.

\section{Acquired obstructive biliary cirrhosis}

In animal experiments Rous and Larimore (1920) showed that occlusion of the common bile duct leads to dilatation of the ducts behind the obstruction. The rise of pressure in the intrahepatic ducts lessens the portal blood flow, and hepatic anoxæmia results. Some of the finer ducts may rupture-Rich (1930) describes this occurrence in man-and the escaped bile is irritant. These two factors produce pericholangitis, with proliferation of the connective tissue of Glisson's capsule and scattered necrosis. Pericholangitic, or periportal, 
cirrhosis is produced, the liver is jaundiced and has a hobnailed appearance, numbers of newly-formed bile ducts appear and small patches of hypertrophied liver parenchyma are found. The human liver is better able to withstand biliary obstruction than the rabbit's, but the same sequence of events is likely to occur with any long-standing obstruction. In addition, especially in calculous cases, infection of the biliary tract may play a part.

Many varieties of obstruction have caused hepatic atrophy and fibrosiscarcinoma, gall stones (Flint, 1937) and pancreatitis (Strauss et al., 1933) are the most important. Rare lesions have been reported in children : stenosis (perhaps congenital) of the common bile duct (Braithwaite, 1934), congenital cystic dilatation of the common bile duct (Wyllie, 1925; Weber, 1934), secondary sarcoma of the pancreas (Crooks, 1925), a tuberculous gland in the hilum of the liver (Ford, 1901). Rolleston (1907) reported syphilitic obstruction of the ducts with syphilitic cirrhosis.

The changes in the liver, apart from jaundice, may be slight or severe. The ducts are dilated and the hepatic changes vary from ' mild central necrosis to acute atrophy, and slight periportal fibrosis to definite cirrhosis' (Flint, 1937). Ascites and splenic enlargement may occur late in the disease, but this stage should not often be reached, as operative relief of the obstruction may restore health to the patient (Strauss et al., 1933).

\section{Congenital biliary cirrhosis and congenital obliteration of the bile ducts}

Congenital obliteration of the bile ducts is usually associated with hepatic cirrhosis, but it does not follow that the cirrhosis is caused by the obstruction.

Rolleston and McNee (1929) consider that toxins pass from the placenta to the foetal liver by the umbilical vein, and also by the ductus venosus into the general circulation and back to the liver by the hepatic artery. The result is cirrhosis with descending obliterative cholangitis. Others (Holmes, 1916 ; Milne, 1912) consider that the primary fault is in the development of the bile ducts, although catarrhal changes may sometimes be important, and obstructive cirrhosis results. The question is still unsettled. This particular type of cirrhosis may occur without any obstruction of the ducts (Gordon, 1922 ; Poynton and Wyllie, 1926 ; Parsons and Hickmans, 1926 ; Munns, 1926), and in any case the intrahepatic biliary channels are not dilated, as might be expected in true obstructive cirrhosis. On the other hand, the disease may occur in only one of twins (Rolleston and McNee, 1929), although it might be expected that a maternal toxin would affect both. Operative treatment of the obstruction, in anatomically suitable instances, has saved a number of patients (Ladd, 1935), but it is noteworthy that some of them had symptoms (presumably caused by cirrhosis) for a considerable time after the operations. Their success means that obstruction may play an important part in the outcome of the disease, but does not prove that atresia causes the cirrhosis.

Whatever the cause, the result is a mixed unilobular and intralobular cirrhosis, with proliferation of small biliary vessels and the presence in the liver of much bile pigment. The hepatic cells may show degenerative changes, the bile passages vary from complete absence to the normal state. Holmes (1916) has given a detailed account of their anomalies.

The clinical features are well known, and the following case report demonstrates some of them :

Case 1. Female, aged three months at death. The parents were healthy; 
there was one sister aged two and a half years. Pregnancy and labour were normal. The birth weight was nine pounds four ounces.

At birth the attendant doctor noticed jaundice. This increased, though there were periods when it was less obvious than at other times. The urine

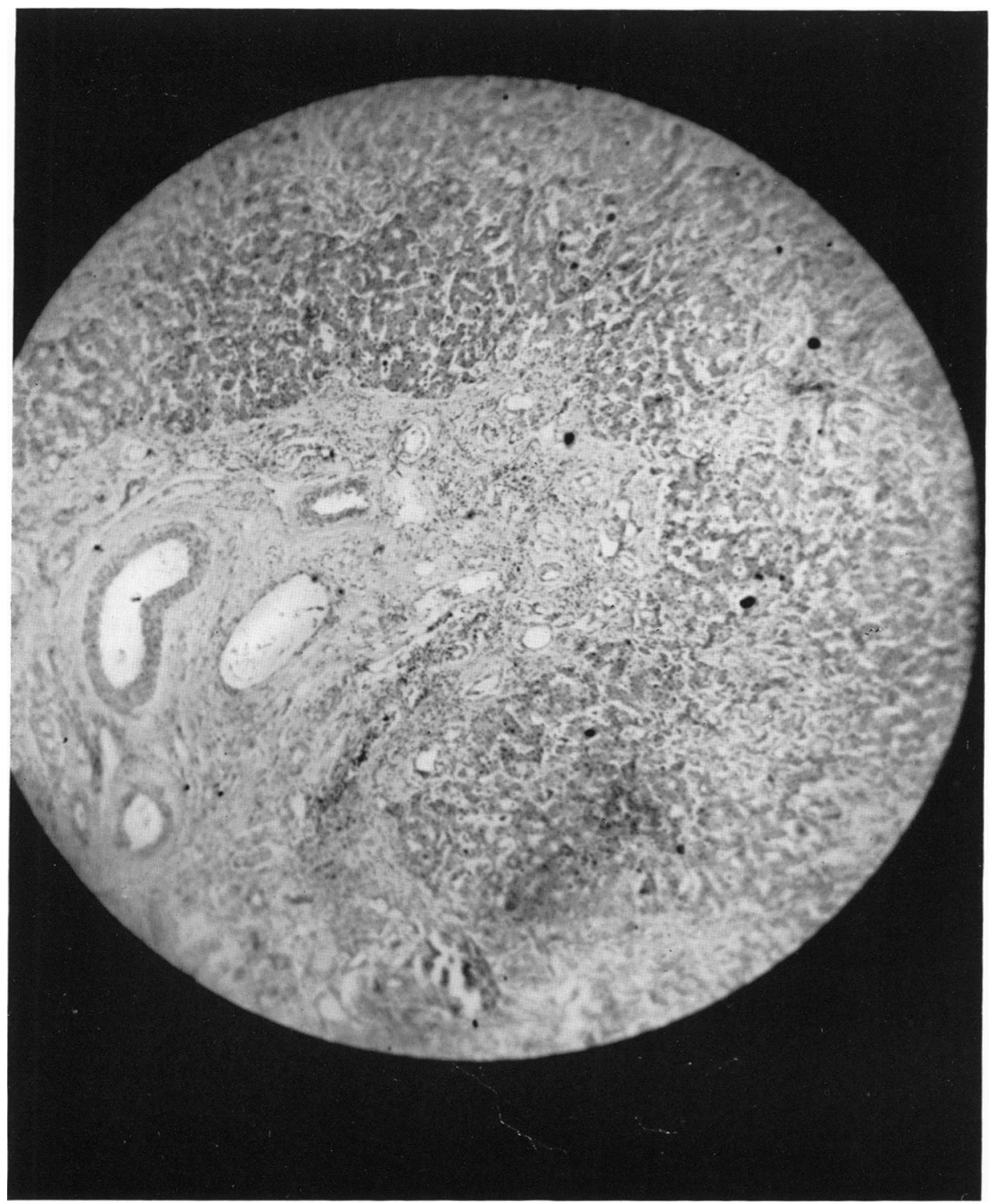

Fig. 1.-Case 1. Liver section. $\times 52$.

was dark yellow and the stools were pale and creamy. The baby was breast fed and was healthy apart from jaundice and stationary weight.

At the age of six weeks she was brought to hospital. The skin and sclerae were dark yellow ; the abdomen was distended and the liver palpable one and 
a half inches below the costal margin. The faeces were almost pure white and the urine contained bile salts. She remained in statu quo for three weeks, when Mr. H. C. Edwards opened the abdomen under local anaesthesia. The liver was found to be large, dark green, firm, and sharp-edged. No gall bladder or bile duct was seen, and no duct was felt in the free edge of the gastrohepatic omentum. The operation was well tolerated, but death occurred after slight diarrhoea and vomiting two and a half weeks later.

AUTOPSY. Wasting and uniform greenish-yellow jaundice were apparent, there was no oedema, no ascites, and no finger clubbing. The liver was smooth, firm, sharp-edged, and dark greenish-grey in colour. The gall bladder was the size of a grain of wheat, and a cord ran from it to the portal fissure. The papilla of Vacer was visible, but no bile ducts could be found. On section, the liver was green, with whitish portal tracts. The hepatic veins, portal veins, and hepatic arteries were normal. No intrahepatic bile ducts were seen. Enlarged lymph glands were found in the portal fissure. The spleen was slightly enlarged and bright red ; it showed no Malpighian corpuscles. The kidneys were bile-stained, and had ' uric acid infarcts.' The meninges were bile-stained, the brain normal.

Microscopical examination of the gastro-hepatic omentum showed no bile duct. In the liver (fig. 1) large portal spaces were seen, with normal portal veins and hepatic arteries which were in a few instances accompanied by bile ducts of normal appearance. The portal spaces also contained many small veins and some arterioles ; central veins were difficult to find; sub-lobular veins appeared normal. Rather loose fibrous tissue extended throughout the portal spaces, around the lobules and to a certain extent within the lobules. Many granular pigmentary deposits of two sorts were visible : first, clusters of greenish-yellow granules lying freely in the connective tissue and in a few cases in the lumina of the bile canaliculi, which also contained mucoid material ; secondly, larger homogeneous brown nodules which were in many cases intracellular. The lobules were broken up by fibrous tissue, and contained many intercellular spaces packed with bile, but the liver cells appeared little damaged.

\section{Non-obstructive biliary cirrhosis : Hanot's syndrome}

Cirrhosis of the liver with jaundice as the predominant feature, but without obstruction of the large bile ducts, is rarely encountered. Although earlier writers (Todd, 1857 ; Hayem, 1874) had described single cases, it was not until Hanot produced his 'Étude sur une forme de cirrhose hypertrophique du foie' in Paris in 1876 that the condition received much attention.

The disease has provided so much material for controversy since then that it is profitable to examine Hanot's account. On the clinical side he described two stages. The first is the stage of onset, characterized by the simultaneous appearance of jaundice and pain or discomfort in the hypochondrium. Other symptoms are anorexia, constipation, malaise, loss of strength and fever. This stage lasts for several weeks, and is succeeded by the stage of chronic jaundice and enlargement of the liver. The jaundice is always present, but is variable, and in fact the disease is characterized by exacerbations and partial remissions of symptoms. The urine is dark, and the faeces are 'sometimes more or less decolorized, and sometimes keep their normal appearance.' The liver varies in size from time to time, it is hard and smooth, and has a sharp lower edge. In the last few months of life the organ may shrink. The spleen is often palpable ; there is no ascites except in some exacerbations and terminally. The end comes in a state of ictère grave. 
That is the clinical picture, and it will be found that the two cases described below follow it fairly closely. Gilbert and Fournier (1895 $a, b)$ emphasized the form of the disease in childhood, when the spleen may become enormous, the fingers may be clubbed, and growth may be arrested. They described illustrative cases in children (Gilbert and Fournier, 1895b) and in an adult (Gilbert and Fournier, 1897). Little has been added to the clinical description since that time. Hanot himself made little of the characteristic haemorrhagic tendency, although in the fifteen cases on which he based his essay, purpura was noted in five instances, epistaxis in four and haemoptysis in two. Three patients vomited blood, and in one of these autopsy revealed oesophageal varices. Varices cannot have caused the non-alimentary haemorrhages, and it is probable that there was prothrombopenia due either to the inability of the damaged liver to manufacture prothrombin or to acholia preventing the absorption of vitamin K (Snell, 1938).

Pathologically, Hanot described a large liver-'a block of fibrous tissue stuffed with relatively widely spaced yellowish or greenish granules.' The anterior border remained sharp, no changes were apparent in the large bile passages, lymphatic glands or blood vessels, except the portal vein, which was sometimes large. The lobules varied from a quarter to four millimetres in diameter, some of them contained large quantities of bile pigment. Many 'pseudo-bile canaliculi' (Hanot did not himself use this term) were present, their cells contained bile, and it was sometimes in the lumen also. Fibrous tissue was present throughout the liver in varying amounts ; it was occasionally perilobular but frequently intralobular. Perihepatitis with diaphragmatic adhesions was common. He summed up the state of the liver as ' an extraand intralobular interstitial hepatitis, with catarrh and abnormal development of the biliary canaliculi.'

The impression is gained of a disease with a clear-cut clinical picture and a pathological picture which was characteristic although subject to considerable variation. For example, the portal vein might be dilated and ascites might be present, whilst increasing fibrosis might reduce the huge proportions of the liver. Nodular hyperplasia was not characteristic, but perusal of the descriptions of Hanot's cases is interesting. One of the fifteen had dilated intrahepatic bile ducts and was probably obstructive in origin, insufficient details are given of another, a third was still living at the time of writing ; of the twelve remaining cases, three had hobnailed livers.

Accounts of typical cases exhibiting Hanot's syndrome have been published by a number of authors. Smith (1898) described three cases with autopsies ; the livers were nodular, but in two of them the fibrosis was described as definitely unilobular. In Taylor's case (1897) the liver was coarsely nodular and was microscopically a 'multilobular' cirrhosis with some fibrosis extending within the masses and occasionally isolating lobules or single cells. Fiessinger, Olivier, and Albot (1929) emphasize that the cirrhosis is not strictly monolobular. Jewesbury's case $(1936,1937)$ exhibited ' multilobular' cirrhosis with many pseudo-bile canaliculi, biliary pigmentation and infiltration with round cells.

Case 2.* Female, aged thirteen years at death. The grandparents and

* This patient was shown at a meeting of the Children's Section of the Royal Society of Medicine in 1936 (Evans, 1937a). 
mother were healthy; the father died of septicaemia. The patient was the fourth of seven children, the eldest died at the age of twenty years of nephritis, one brother (the fifth child) died at the age of four weeks of jaundice.

This girl's illness started at the age of eight years and ran its course in five years. In August, 1932, she had an attack of vomiting, jaundice, pale stools, dark urine and abdominal enlargement. The symptoms lasted for ten weeks. In December, 1932, she had a similar attack, and the liver was found to be enlarged two fingersbreadths below the costal margin, the spleen was just palpable, the urine contained bile salts and pigments, and the stools were pale. In January, 1933, she appeared to have recovered completely, but although she was not clinically jaundiced, the direct van den Bergh reaction was positive and the indirect 10 units. At this time she had a whitlow, the first of a long series of septic lesions from which staphylococcus aureus was regularly recovered on culture. The blood count at this time was normal (table 1).

TABLE 1

BLOOD COUNTS IN CASE 2

\begin{tabular}{|c|c|c|c|c|c|c|c|c|c|c|}
\hline YEAR & MONTH & DAY & $\begin{array}{c}\text { RED } \\
\text { BLOOD } \\
\text { CELLS } \\
\text { (MIL- } \\
\text { LION) }\end{array}$ & $\begin{array}{l}\text { HAEMO- } \\
\text { GLOBIN } \\
\text { PER } \\
\text { CENT. }\end{array}$ & $\begin{array}{l}\text { COLOUR } \\
\text { INDEX }\end{array}$ & $\begin{array}{l}\text { WHITE } \\
\text { BLOOD } \\
\text { CELLS }\end{array}$ & $\begin{array}{l}\text { POLYS. } \\
\text { PER } \\
\text { CENT. }\end{array}$ & $\begin{array}{c}\text { EOS. } \\
\text { PER } \\
\text { CENT. }\end{array}$ & $\begin{array}{l}\text { LYM. } \\
\text { PER } \\
\text { CENT. }\end{array}$ & REMARKS \\
\hline 1933 & Jan. & 10 & $4 \cdot 66$ & 92 & 0.98 & 5,400 & 53 & 2 & 45 & - \\
\hline 1933 & Mar. & 22 & $2 \cdot 65$ & 50 & 0.94 & - & - & - & - & Abscess. \\
\hline 1934 & July & 16 & - & - & - & 3,400 & 36 & 3 & 61 & Abscess. \\
\hline 1934 & July & 19 & - & - & - & 3,400 & - & - & - & Abscess opened. \\
\hline 1934 & July & 25 & - & - & - & 1,200 & 43 & 9 & 44 & - \\
\hline 1934 & July & 31 & - & - & - & 4,300 & 74 & 6 & 20 & $\begin{array}{l}\text { Pentnucleotide } \\
12 \mathrm{~d} \text { c.c. July } 18- \\
\text { Aug. } 1 \text {. }\end{array}$ \\
\hline 1934 & Aug. & 4 & - & - & - & 3,400 & 66 & 6 & 27 & - \\
\hline 1934 & Aug. & 10 & - & - & - & 1,000 & 36 & 10 & 53 & - \\
\hline 1934 & Nov. & 17 & $3 \cdot 63$ & 74 & $1 \cdot 02$ & 3,000 & 48 & 6 & 45 & Acute nephritis. \\
\hline 1935 & Oct. & 23 & $5 \cdot 10$ & 100 & 0.98 & 3,000 & 50 & 5 & 40 & $\begin{array}{l}\text { Cyanosis devel- } \\
\text { oped. }\end{array}$ \\
\hline 1935 & Nov. & 12 & $4 \cdot 71$ & 96 & $1 \cdot 02$ & 3,400 & 51 & 5 & 43 & - \\
\hline 1936 & Feb. & 24 & $5 \cdot 98$ & 102 & 0.85 & 6,200 & 66 & 4 & 25 & - \\
\hline 1936 & Apr. & 1 & $5 \cdot 64$ & 102 & 0.90 & 6,400 & 66 & 8 & 19 & - \\
\hline 1937 & Jan. & - & - & - & - & 4,600 & 55 & 1 & 39 & Abscess. \\
\hline 1937 & Mar. & - & $5 \cdot 18$ & 106 & 0.98 & 4,000 & 57 & 2 & 38 & $\begin{array}{c}\text { One week after } \\
\text { haematemesis. }\end{array}$ \\
\hline
\end{tabular}

Poly. =neutrophil polymorphonuclear leucocytes.

Eos. = eosinophil polymorphonuclear leucocytes.

Lym. $=$ lymphocytes.

Her weight was slightly below Holt's normal, but a noteworthy feature of the illness was the way in which she recovered weight after losing it (table 2), and her nutrition was good throughout.

From May to October, 1933, she suffered from some abdominal pain and variable pyrexia, with enlargement of the liver and spleen. The liver remained large, but the spleen receded beneath the costal margin. The Wassermann reaction at this time was negative, as it was on other occasions. A slight diminution of red cell fragility was shown by the quantitative method (Dr. E. ff. Creed). Her serum did not agglutinate B. typhosus, paratyphosus A, B, C, melitensis or Br. abortus. 
TABLE 2

BODY WEIGHT, CASE 2

\begin{tabular}{cc|c|c}
\hline \multicolumn{2}{c|}{$\begin{array}{c}\text { AGE } \\
\text { YEARS }\end{array}$} & MONTHS & $\begin{array}{c}\text { PATIENT'S WEIGHT } \\
\text { (POUNDS) }\end{array}$ \\
\hline 8 & 11 & 47 & $\begin{array}{c}\text { NORMAL (HOLT) } \\
\text { (POUNDS) }\end{array}$ \\
9 & 1 & 52 & 57 \\
9 & 4 & 48 & 58 \\
9 & 8 & 61 & 61 \\
10 & 1 & 57 & 63 \\
10 & 7 & 57 & 67 \\
11 & 3 & 72 & 73 \\
11 & 10 & 68 & 79 \\
12 & 7 & 68 & 84 \\
12 & 11 & 69 & 87 \\
\hline
\end{tabular}

In November, 1933, septic lesions appeared, and in February, 1934, she was again deeply jaundiced. An abscess over the scapula was incised, but did not heal for two months. She was severely anaemic. The jaundice eventually disappeared, but soon reappeared with further abscesses in July. She was acutely ill at this time, and developed grave leucopenia. Injections of pentnucleotide accompanied a temporary increase of granulocytes, and she recovered.

In November, 1934, she had acute nephritis (blood urea $66 \mathrm{mgm}$. per 100 c.c., $37 \mathrm{mgm}$. six weeks later) with ascites and bilateral hydrothorax. The signs of renal failure rapidly disappeared, but she had microscopic and sometimes gross haematuria intermittently for the rest of her life-" une véritable néphrite biliaire,' as Gilbert and Lereboullet (1900) call it.

In August, 1935, cyanosis and dyspnoea on exertion were gradually noticed. In October she had an attack of abdominal pain, increased jaundice and fat intolerance. The liver was enlarged two, and the spleen four fingersbreadths. She had a dusky café au lait skin with considerable cyanosis of the lips, tongue, and nail-beds. The fingers and toes were clubbed. No abnormality of heart or lungs was discovered.

She recovered from the abdominal disturbance, but dyspnoea and cyanosis persisted, and the girl herself complained of breathlessness as the most severe symptom for the rest of her life. After the development of cyanosis she was never found to be anaemic. In time the leucopenia also disappeared.

In June, 1936, gross haematuria recurred, but she subsequently remained fairly well until, in January, 1937, an abscess in the leg brought her to hospital again. She returned home, but was unable to go out for walks as she was too dyspnoeic. On March 1 she vomited blood three times. She was said to have ejected between one and two pints, but when she came to hospital a week later because of increased jaundice and swelling of the abdomen and legs, she was found to be polycythaemic. The spleen and liver were still enlarged, although the latter had contracted so that it only extended one inch below the costal margin. She was ascitic, but no veins were seen on the abdominal wall. The urine did not at this time contain blood or albumin. Treatment with salyrgan caused copious diuresis and a reduction in the size of the abdomen. She was discharged, but a month later she was admitted to another hospital in cholaemia and died.

AUTOPSY. ${ }^{*}$ There was jaundice and slight wasting. A small amount of

* I am indebted to the Medical Superintendant of Dulwich Hospital for allowing me to be present at the autopsy, and to take these notes. 
bile-stained fluid was present in the abdomen ; all tissues were bile-stained. Abscesses were present in the following situations : one, two inches in length, in the second intercostal space, pointing subpleurally and extending to the rib ; one behind the pelvis of the right kidney; and a large number in the kidney cortex. The larynx, trachea, bronchi and right lung were normal ; there was some interstitial haemorrhage in the left lung. The heart, aorta, inferior vena cava, common iliac veins, hepatic veins, portal vein, splenic vein and vasa brevia were normal. There was slight varicosity of the oesophageal veins, but

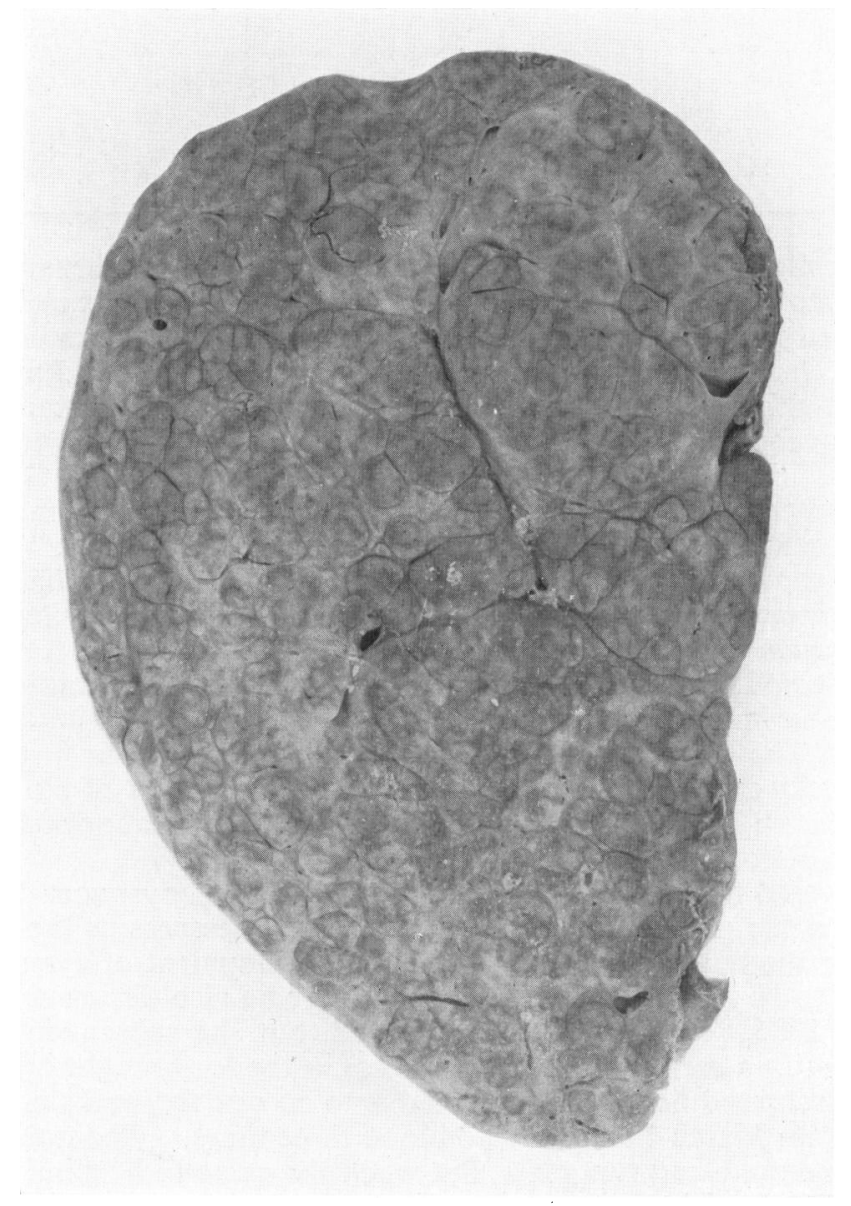

FIG. 2.-Case 2. Liver, cut surface, natural size.

no rupture seen. The stomach was dilated, containing half a pint of blood. The pancreas and intestines were normal. Liver: the right lobe was coarsely nodular (fig. 2) and yellow, the edges rounded, the diameter about six inches. The left lobe was small, two inches in diameter, similar in appearance, and joined to the right by a band two inches broad and four inches long and oneeighth of an inch thick, of dark red tissue (presumably capsule and attenuated liver substance). On section, nodules up to half an inch in diameter were seen, light greenish yellow in colour and separated by grey-brown matrix. Removal 
of the nodules of hepatic tissue by blunt dissection showed that they were separated by thin fibrous walls which appeared to take their shape from the contiguous nodules rather than to be moulding the nodules by compression.

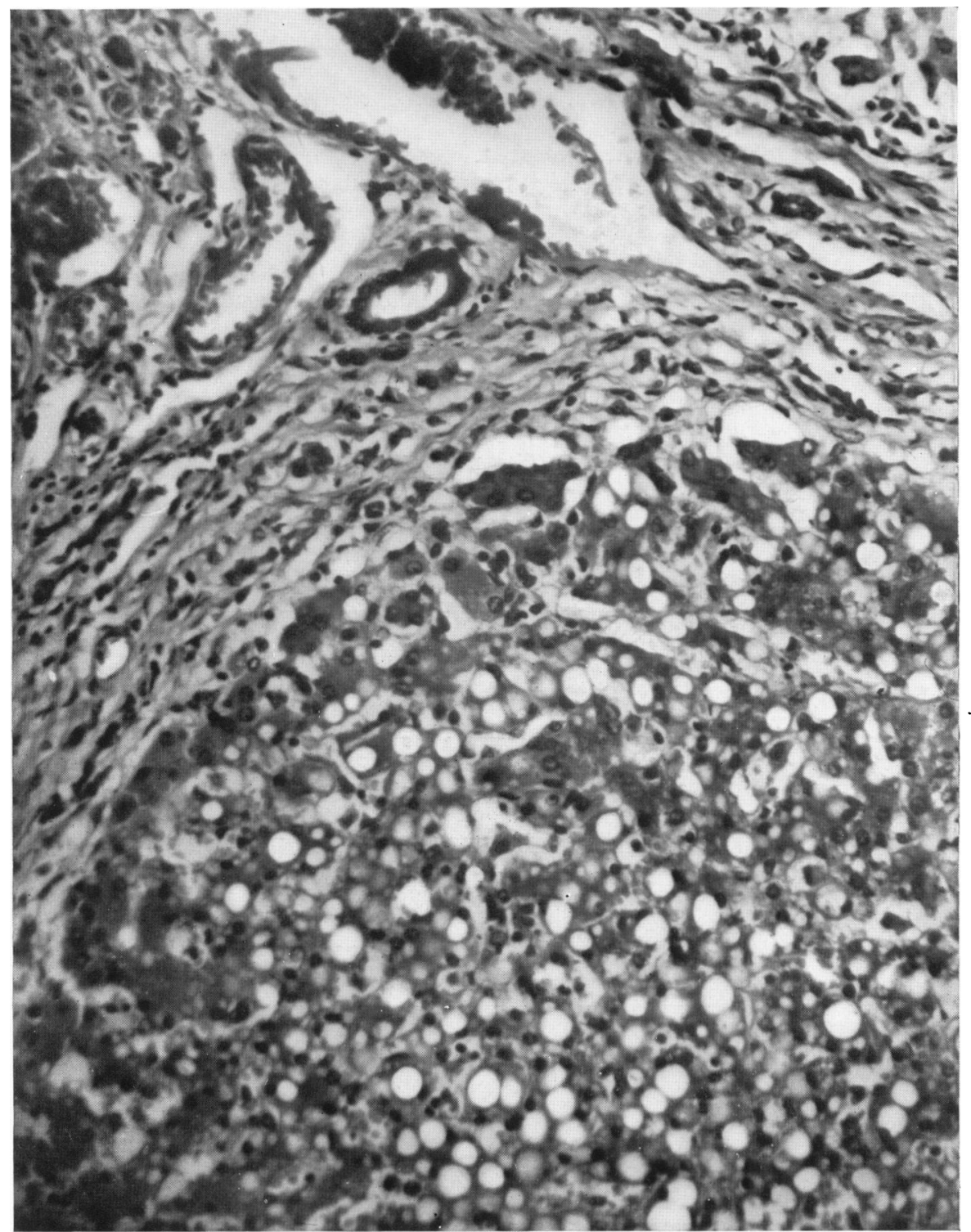

Fig. 3.-Case 2. Liver section. $\quad \times 284$.

The spleen was ten inches long, dark red and soft.

The kidneys were large and dark in colour and pyaemic abscesses were present.

Microscopical Examination. Liver (fig. 3): Hepatic arterioles were normal. The portal venules varied, some being large and patent and some 
compressed. The large bile ducts were normal; the smaller ducts showed desquamation of mucous membrane. Pseudo-bile canaliculi were present, but were not patent. Fibrous tissue was cellular and contained many lymphocytes and a number of thin-walled blood vessels. The liver nodules were clearly defined. The liver cells were vacuolated, otherwise in some parts normal but in others staining badly and containing deposits of greenish yellow pigment.

Left lung: the alveolar walls were thickened by congestion, leucocytic infiltration and some fibrosis.

Spleen : patchy fibrosis was present.

Kidney : pyaemic abscesses, glomerulocapsular adhesions, and patchy congestion were seen.

This patient's clinical features were those of Hanot's syndrome. The abnormalities seen post mortem were consistent with those observed in some of Hanot's cases, and with others since described. Phillips (1937) recently described a similar case which was also characterized by recurring staphylococcal infections and death from pyaemia.

TABLE 3

VAN DEN BERGH REACTIONS, CASE 2

\begin{tabular}{|c|c|c|}
\hline DATE & $\begin{array}{l}\text { HAEMOBILIRUBIN MGM. PER } \\
100 \text { C.C. (NORMAL } 0 \cdot 1-0 \cdot 3 \text { ) }\end{array}$ & $\begin{array}{l}\text { CHOLEBILIRUBIN MGM. PER } \\
100 \text { C.C. (NORMAL 0) }\end{array}$ \\
\hline $\begin{array}{l}\text { 1933, Jan. } \\
\text { 1933, Oct. } \\
\text { 1933, Nov. } \\
\text { 1935, Oct. }\end{array}$ & $\begin{array}{c}+ \\
0.1 \\
0.6 \\
1.1\end{array}$ & $\frac{t}{2 \cdot 8} \frac{t}{3 \cdot 1}$ \\
\hline
\end{tabular}

TABLE 4

LAEVULOSE TOLERANCE TESTS, CASE 2

\begin{tabular}{|c|c|c|c|c|c|}
\hline & & & & \multicolumn{2}{|c|}{ BLOOD SUGAR PER CENT. } \\
\hline & & & & OCTOBER 1933 & OCTOBER 1935 \\
\hline $\begin{array}{l}\text { Before } 50 \text { gm. laevulose } \\
\text { Half an hour after } \\
\text { One hour after } \\
\text { One and a half hours after } \\
\text { Two hours after }\end{array}$ & $\begin{array}{l}\cdots \\
\cdots \\
\cdots \\
\cdots\end{array}$ & $\begin{array}{l}\cdots \\
\cdots \\
\cdots \\
\cdots \\
\cdots\end{array}$ & $\begin{array}{l}\cdots \\
\cdots \\
\cdots \\
\cdots \\
\cdots\end{array}$ & $\begin{array}{l}0 \cdot 095 \\
0 \cdot 113 \\
0 \cdot 111 \\
0 \cdot 125 \\
0 \cdot 114\end{array}$ & $\begin{array}{l}0.081 \\
0 \cdot 111 \\
0 \cdot 122 \\
0.095 \\
0.093\end{array}$ \\
\hline
\end{tabular}

The laboratory investigations require little comment. A positive direct and indirect van den Bergh reaction (table 3 ) has been noticed previously (Phillips, 1937). The laevulose tolerance test indicated some liver damage (table 4). Anaemia with leucopenia was present in this as in many other cases of severe hepatic dysfunction. The anaemia was normochromic, but it disappeared with the onset of cyanosis and was succeeded by slight polycythaemia, which has been previously noticed in Hanot's cirrhosis (Rolleston and McNee, 1929). A recurrence of nephritis did not reproduce anaemia. Leucopenia 
has been observed in biliary cirrhosis, but leucocytosis is more common, as it occurred in fifteen out of twenty-five recorded cases (Rolleston and McNee, 1929 ; Hanot and Meunier, 1895 ; Taylor, 1895, 1897 ; Fiessinger, Olivier and Albot, 1929 ; Chiroy, Albot and Malinsky, 1935). Neutropenia and lymphopenia occurred in response to staphylococcal sepsis in 1934, and injections of pentose nucleotide were accompanied by a transient rise of the neutrophil count. Eventually, after the anaemia had disappeared, the white count returned to normal, the whole course of events suggesting that the marrow was potentially sound. Mild eosinophilia was sometimes present, as it was also in the second case recorded by Fiessinger, Olivier and Albot (1929).

Finger clubbing is common in biliary cirrhosis in childhood (Gilbert and Fournier, 1895 ; Taylor, 1895), although the cause has been even more obscure than in pulmonary and cardiac conditions. It has also occurred in patients with liver abscess (Locke, 1915), syphilitic stricture of the common bile duct (Rolleston, 1907), rarely in portal cirrhosis (Rolleston and McNee, 1929) and in some other diseases of the alimentary system, for example idiopathic steatorrhea (Bennett, Hunter and Vaughan, 1932, Evans, 1934) and polyposis of the colon (Ellis, 1938).

The severe and prolonged cyanosis observed in this child suggests a connexion with pulmonary and cardiac clubbing, but the cause of the cyanosis itself is not clear. Congenital heart disease was easily ruled out. Spectroscopy revealed no abnormal pigment in the blood (Dr. R. A. McCance). Peripheral stagnation and deoxygenation of the blood cannot have been the main cause, for the femoral arterial blood was already partly deoxygenated (table 5).

TABLE 5

BLOOD OXYGEN, CASE 2, FEB. 1936 (DR. D. W. BROOKES)

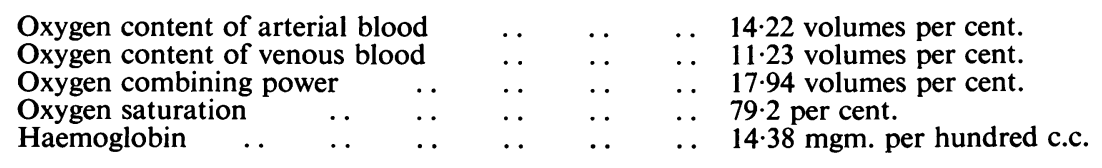

The arm-to-carotid circulation time by the potassium cyanide method was seven seconds (adult normal nine to twenty-one seconds), which also makes peripheral stagnation improbable. Another possibility is that pulmonary oxygenation was inefficient, and indeed, when the patient was placed in an oxygen tent the cyanosis was reduced when the oxygen concentration reached forty per cent., but even sixty per cent. did not abolish the purple tint. A skiagram of the chest and post-mortem examination of the lungs did not support this theory.

Keys and Snell (1938) have shown that the oxygen saturation of the arterial blood is frequently reduced in liver disease, with or without anaemia. This is considered to be due to 'an alteration in the fundamental affinity between haemoglobin and oxygen,' and the cyanosis may be temporarily reduced by the transfusion of normal blood (Judd, Snell and Hoerner, 1935). 
Case 3.* A female was aged seven years at the onset of the disease. The parents were healthy ; the mother had one tubal pregnancy and one healthy daughter, and no miscarriages. The patient's health was good, except during attacks of measles, mumps and whooping cough, until in April, 1935, she developed jaundice, followed by diarrhoea and vomiting. Jaundice was continually present, with exacerbations, during the twenty-two months for which information is available, but the vomiting and epigastric pain which accompanied it became progressively rarer. The stools were pale and bulky and the urine highly coloured. At times she seemed feverish.

On examination in December, 1935, she had scleral and cutaneous jaundice. The spleen extended one and the liver three fingersbreadths below the costal margin. The urine contained albumin, bile salts and bile pigments. The blood count is shown in table 6. There was no increase in blood fragility. The serum contained $1.2 \mathrm{mgm}$. haemobilirubin and $0.08 \mathrm{mgm}$. cholebilirubin per 100 c.c. The Wassermann reaction was read as weakly positive on December 11 and positive on December 24. The mother's Wassermann reaction was weakly positive.

TABLE 6

BLOOD COUNTS, CASE 3

\begin{tabular}{c|c|c|c|c|c|c|c|c|c}
\hline YEAR & MONTH & $\begin{array}{c}\text { RED } \\
\text { BLOOD } \\
\text { CELLS } \\
\text { IN MIL- } \\
\text { LION }\end{array}$ & $\begin{array}{c}\text { HAEMO- } \\
\text { GLOBIN } \\
\text { PER } \\
\text { CENT. }\end{array}$ & $\begin{array}{c}\text { COLOUR } \\
\text { INDEX }\end{array}$ & $\begin{array}{c}\text { WHITE } \\
\text { BLOOD } \\
\text { CELLS }\end{array}$ & $\begin{array}{c}\text { POLYS. } \\
\text { PER } \\
\text { CENT. }\end{array}$ & $\begin{array}{c}\text { EOS. } \\
\text { PER } \\
\text { CENT. }\end{array}$ & $\begin{array}{c}\text { LYM. } \\
\text { PER } \\
\text { CENT. }\end{array}$ & REMARKS \\
\hline 1935 & Dec. & $4 \cdot 14$ & 94 & $1 \cdot 14$ & 10,000 & 50 & $2 \cdot 5$ & 46 & $\begin{array}{c}\text { Reticulocytes } 1 \cdot 2 \\
\text { per cent. } \\
\text { Recticulocytes } 1 \\
\text { per cent. }\end{array}$ \\
1936 & Mar. & $4 \cdot 10$ & 82 & $1 \cdot 0$ & 6,600 & 70 & 1 & 28 & 47 \\
\hline
\end{tabular}

In one month the jaundice disappeared and the liver was felt to be one fingersbreadth smaller (hexamine was being given at this time). Between January and March, 1936, ten injections of 0.5 c.c. of bismostab were given. In March, 1936, she was readmitted to hospital because she complained of increased jaundice and epigastric pain. The serum contained $1.25 \mathrm{mgm}$. haemobilirubin and $3.35 \mathrm{mgm}$. cholebilirubin per 100 c.c. at this time, and the possibility of obstruction of the large bile ducts was considered. Cholecystography showed a faint shadow at twenty hours. The blood sugar was 0.066 per cent. before $50 \mathrm{gm}$. of laevulose were given, 0.088 per cent. at half an hour, 0.109 per cent. at one hour, 0.117 per cent. at one and a half hours, 0.131 per cent. at two hours. On June $3 \mathrm{Mr}$. H. C. Edwards performed a laparotomy. The gall bladder was large, white and thick-walled; the common bile duct looked normal. Cholecystgastrostomy was performed and the operation terminated. Despite post-operative collapse of the right lung, recovery was rapid and the patient was discharged from hospital.

In February, 1937, she was seen again. She had not benefited from the operation ; jaundice was variable but always present, the urine contained bile pigments, but Hay's test was negative. The stools varied in colour. She had occasional epigastric pain and much flatulence. She was well nourished, but had not gained weight in eight months (table 7). The liver was hard but little

* This patient was shown before a meeting of the Children's Section of the Royal Society of Medicine in 1937 (Evans, 1937b). 
enlarged, the spleen extended three fingersbreadths below the costal margin. The gastric residuum contained free hydrochloric acid and much bile. The Wassermann reaction was doubtful.

TABLE 7

WEIGHT, CASE 3

\begin{tabular}{cc|c|c}
\hline \multicolumn{2}{c}{ AGE } & & $\begin{array}{c}\text { WEIGHT } \\
\text { (POUNDS) }\end{array}$ \\
\hline 7 & 10 & 56 & $\begin{array}{c}\text { NORMAL WEIGHT FOR AGE (HOLT) } \\
\text { (POUNDS) }\end{array}$ \\
\hline 7 & 11 & 59 & 52 \\
8 & 1 & 61 & 52 \\
8 & 2 & 62 & 53 \\
8 & 4 & 64 & 54 \\
9 & 0 & 64 & 58 \\
\hline
\end{tabular}

The liver was seen at operation to be coarsely nodular. A piece was removed for microscopical examination (fig. 4). A section showed nodules of liver cells embedded in fibrous tissue, some strands of which extended into the nodules. These consisted of distorted, vacuolated cells with basophilic cytoplasm, arranged irregularly. No central veins were seen. The fibrous tissue was cellular and moderately dense ; it contained a number of lymphocytes and ill-defined pseudo-bile canaliculi which appeared to be compressed. On the edges of some nodules were large cells containing groups of yellowgreen granules and from one to five nuclei. The few blood vessels which could be seen were patent.

This child's illness followed a course similar to the earlier part of that in case 2, and it is reasonable to make a similar diagnosis. Syphilis must, however, also be considered. The Wassermann reaction is stated by Lange (1922) to be unreliable if there is retention of bile salts, but the mother's weakly positive reaction makes it likely that, despite the absence of stigmata, the daughter had congenital syphilis. The condition of the liver is, nevertheless, different from any recognized type of syphilitic hepatitis. It is possible, as Rolleston and McNee (1929) suggest, that after recovery from congenital syphilis the liver may be unusually susceptible to other agents which may cause hepatic damage.

\section{Other types of biliary cirrhosis}

The picture of non-obstructive biliary cirrhosis presented in the cases cited above resembles that of subacute yellow atrophy (e.g. Broadbent, 1905 ; Chisholm, 1914), and it must be admitted that the dividing line is not hard and fast, but there are some differences. Subacute yellow atrophy is caused by certain known and some unknown toxins, whilst the cause of non-obstructive biliary cirrhosis is not known. The former condition has a progressive course in fatal cases, jaundice is not always a pronounced feature, portal failure may occur early, and death is likely to supervene after weeks or months. The cirrhosis also has a progressive course, but with many exacerbations and remissions, jaundice occurs early and is frequently deep, portal failure is late in appearance, and the patient dies after years of illness. Finger clubbing is 
not a feature of subacute atrophy. At autopsy the cirrhotic liver is slate green or yellow green on grey ground if nodular hyperplasia has occurred. The liver in subacute yellow atrophy consists of yellow nodules on a red back-

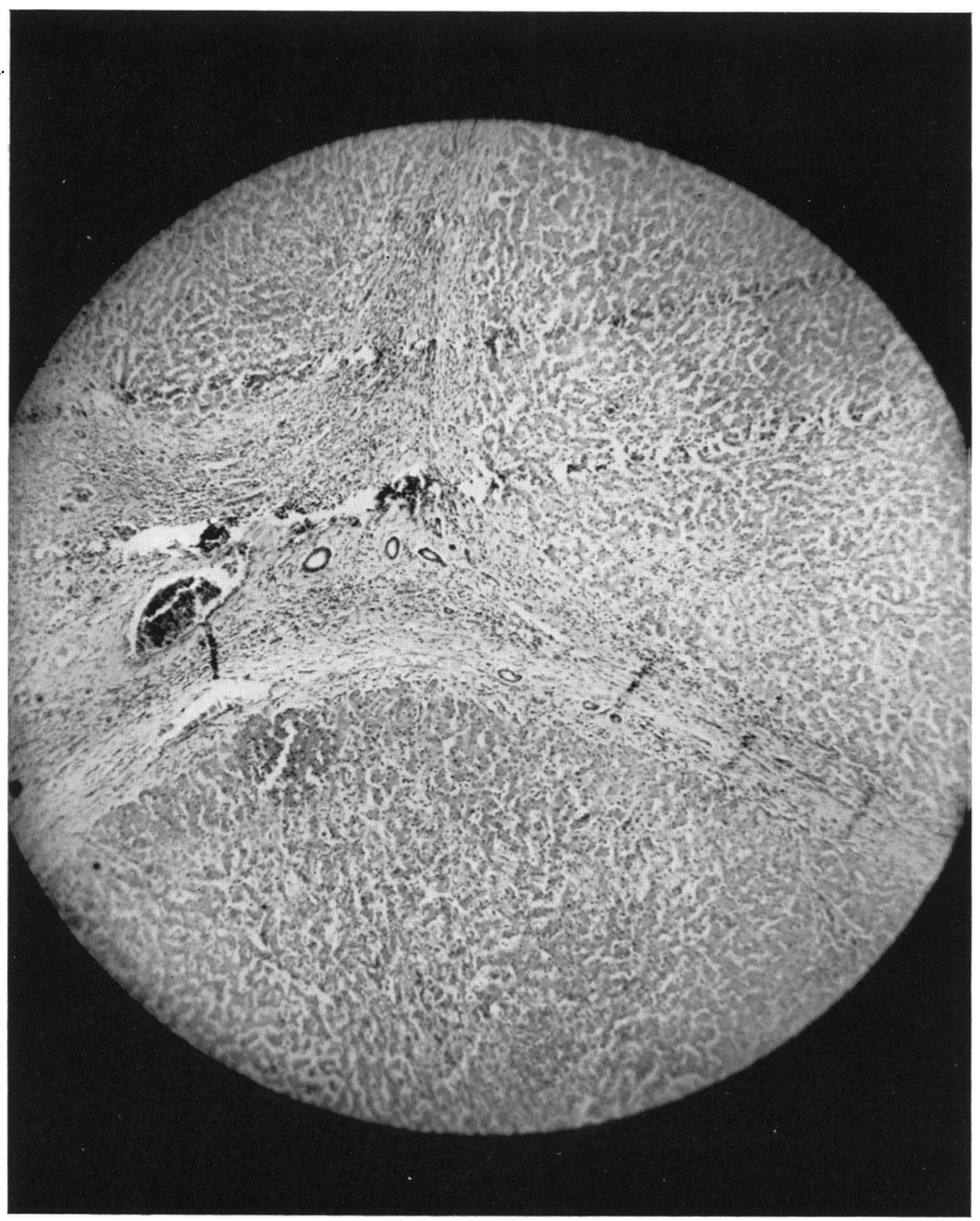

Fig. 4.-Case 3. Liver section. $\quad \times 52$.

ground of granulation tissue. It is difficult to say how important these differences are, and it may be that biliary cirrhosis should be regarded as chronic yellow atrophy.

Mention is occasionally made of biliary cirrhosis without jaundice (e.g. Rolleston and Wyard, 1920), but few cases have been described. In the section 
on hepatic cirrhosis of Nobécourt and Babonneix's Traité de Médecine des Enfants (1934) a picture of the microscopic appearance of perfect monolobular cirrhosis is used to illustrate the account of biliary cirrhosis. The preparation was made from the liver of a child with ' cirrhose biliaire sans ictère' described by Lereboullet in 1901. Clinically and pathologically the resemblance to the following case is striking.

Case 4.* A male, aged six years and nine months at death, was the sixth of eight children, and born of healthy parents in 1930. He suffered from occasional epistaxis, but the parents noticed nothing else wrong. At the age of four and a half years a school doctor referred him to hospital on account of enlargement of the liver and spleen.

On examination in January, 1935, he was seen to be sallow and thin, but his general condition was good and his weight thirty-three pounds. There were a few telangiectases on his face. The liver was uniformly enlarged three inches below the costal margin and was hard. The spleen extended two inches below the costal margin. Jaundice, ascites and haemorrhoids were absent. The Wassermann reaction was negative. The serum contained $0.3 \mathrm{mgm}$. haemobilirubin per 100 c.c. The blood sugar before $50 \mathrm{gm}$. of laevulose was 0.095 per cent., half an hour after it was 0.107 per cent., one hour after 0.095 per cent., one and a half hours after 0.103 per cent., two hours after 0.095 per cent.

He remained well, and gained two pounds in weight, until September, 1935, when he had two haematemeses, associated with melaena. Apart from anaemia and leucopenia (table 8) his condition appeared to be unchanged.

TABLE 8

BLOOD COUNTS, CASE 4

\begin{tabular}{|c|c|c|c|c|c|c|c|c|c|c|}
\hline YEAR & MONTH & DAY & $\begin{array}{c}\text { RED } \\
\text { BLOOD } \\
\text { CELLS } \\
\text { MIL- } \\
\text { LION }\end{array}$ & $\begin{array}{c}\text { HAEMO- } \\
\text { GLOBIN } \\
\text { PER } \\
\text { CENT. }\end{array}$ & $\begin{array}{l}\text { COLOUR } \\
\text { INDEX }\end{array}$ & $\begin{array}{l}\text { WHITE } \\
\text { BLOOD } \\
\text { CELLS }\end{array}$ & \begin{tabular}{|c|} 
POLYS. \\
PER \\
CENT.
\end{tabular} & $\begin{array}{l}\text { EOS. } \\
\text { PER } \\
\text { CENT. }\end{array}$ & $\begin{array}{l}\text { LYM. } \\
\text { PER } \\
\text { CENT. }\end{array}$ & REMARKS \\
\hline $\begin{array}{l}1935 \\
1935\end{array}$ & $\begin{array}{l}\text { Jan. } \\
\text { Sept. }\end{array}$ & - & $\begin{array}{l}4 \cdot 92 \\
3 \cdot 30\end{array}$ & $\begin{array}{l}92 \\
62\end{array}$ & $\begin{array}{l}0.93 \\
0.9\end{array}$ & $\begin{array}{l}8,600 \\
2,800\end{array}$ & $\begin{array}{l}81 \\
81\end{array}$ & $\begin{array}{l}7 \\
1\end{array}$ & $\begin{array}{l}11 \\
12\end{array}$ & $\underset{\text { mesis. }}{\text { After }}$ haemate- \\
\hline 1936 & Nov. & - & $2 \cdot 54$ & 53 & 1.04 & 7,200 & 82 & 1 & 10 & $\begin{array}{l}\text { After haemate } \\
\text { mesis. }\end{array}$ \\
\hline 1936 & Dec. & 3 & $2 \cdot 12$ & 42 & 0.99 & 5,600 & 79 & 0 & 13 & - \\
\hline 1936 & Dec. & 15 & $3 \cdot 71$ & 70 & 0.94 & - & - & - & - & After transfusion. \\
\hline 1937 & Jan. & 26 & $2 \cdot 84$ & 57 & $1 \cdot 01$ & - & 一 & - & - & $\begin{array}{l}\text { After haemate- } \\
\text { mesis. }\end{array}$ \\
\hline 1937 & Feb. & 20 & $3 \cdot 90$ & 80 & 1.03 & - & - & - & - & $\begin{array}{l}\text { Before haeme- } \\
\text { mesis. }\end{array}$ \\
\hline 1937 & Mar. & 5 & 一 & 60 & 一 & 一 & - & - & 一 & - \\
\hline 1937 & Mar. & 16 & - & $\begin{array}{l}64 \\
70\end{array}$ & - & - & 一 & 二 & 二 & After transfusion \\
\hline $\begin{array}{l}1937 \\
1937\end{array}$ & $\begin{array}{l}\text { Mar. } \\
\text { Mar. }\end{array}$ & $\begin{array}{l}18 \\
30\end{array}$ & - & $\begin{array}{l}70 \\
78\end{array}$ & - & - & - & - & - & After transfusion. \\
\hline
\end{tabular}

After this he was again fairly well, though the liver and spleen gradually extended about an inch lower. In November, 1936, he had a large haematemesis, and was readmitted to hospital. He was pale and pyrexial $\left(99^{\circ} \mathrm{F}\right.$. to $105^{\circ} \mathrm{F}$. for two weeks), but had gained weight (to thirty-seven pounds).

* This child was exhibited before the Clinical Section of the Royal Society of Medicine two years before his death, as a case of portal cirrhosis (Newns, 1935). 
Part of this gain was due to ascites, which was easily demonstrable. While he was pyrexial the cardiac apex beat was found to be external to the nipple line, gallop rhythm was present and there were loud apical and basal systolic murmurs.

The condition gradually improved, and a month later there were no definite signs of disease except enlargement of the liver and spleen. The blood count was still low, and on December 12 a transfusion of 350 c.c. of the father's blood was given. On December 16 there was another haematemesis. It was followed by a temperature of about $100^{\circ} \mathrm{F}$. for two weeks, and ascites reappeared. This was present for the rest of the child's life. Progress was uneventful until January 25,1937 , when a further haematemesis occurred.

A red blood count on February 20 was nearly normal, but that evening he

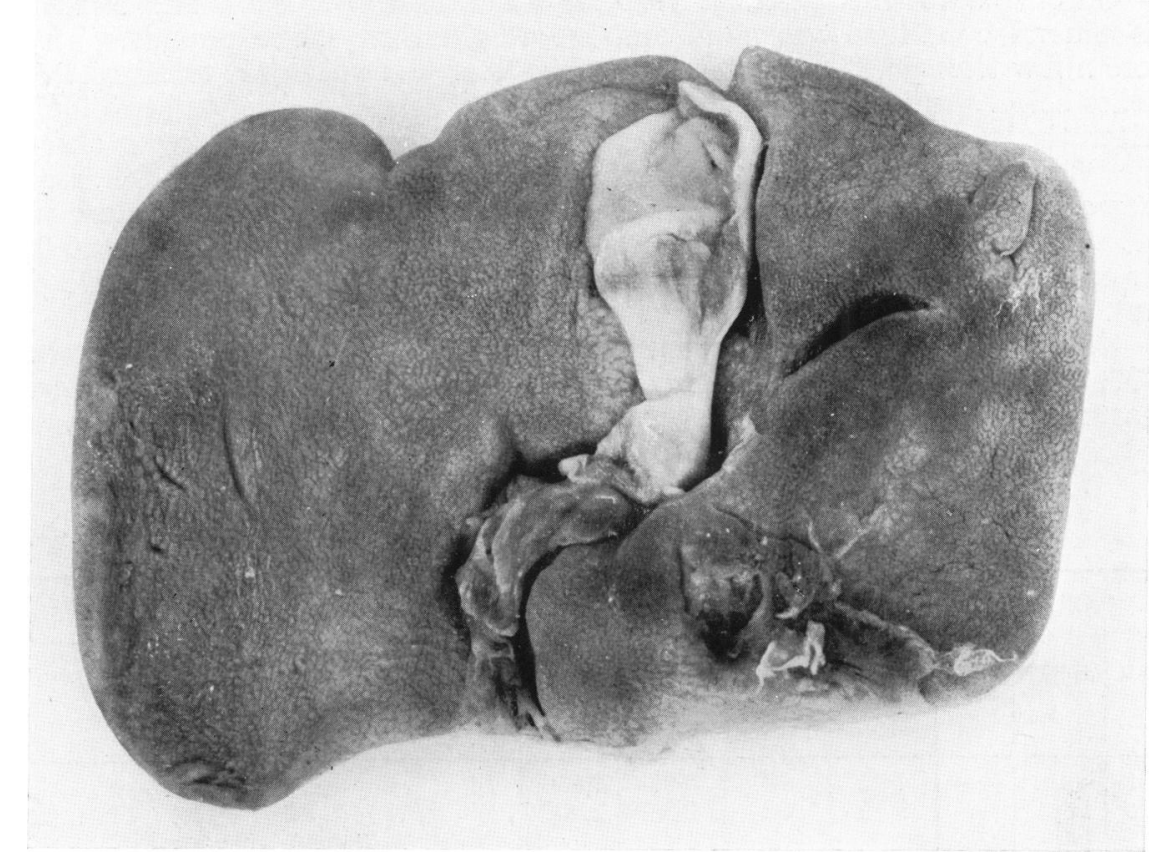

Fig. 5.-Case 4. Liver. (Infra-red photograph by Miss Josephine Hunt.)

had another haematemesis. The liver and spleen appeared to become smaller a few hours (not immediately) after each haematemesis, but it was impossible to be sure that this appearance was not caused by variation in the amount of ascites.

The haemoglobin percentage was sixty on March 5, and sixty-four per cent. on March 16, so a transfusion was given on the following day, 100 c.c. of citrated blood raising the figure to seventy per cent. On March 30 it was seventy-eight per cent.

On April 1 the abdomen was opened by a left upper paramedian incision under ether anaesthesia. The spleen was removed with little difficulty, but respiration ceased rather suddenly as the wound was being closed, and despite restorative measures the boy died. He was six years and nine months old.

At autopsy nothing abnormal was found outside the abdomen, with the exception of large varicose veins at the lower end of the oesophagus. The spleen was large and firm. The liver was large and hard (fig. 5). Its 
surface was smooth, but innumerable fawn-coloured nodules, mostly about one $\mathrm{mm}$. in diameter, were visible beneath the peritoneum. The cut surface showed innumerable nodules of fawn-coloured hepatic tissue, some circular in section but mostly irregular, some branching, none more than two $\mathrm{mm}$. in

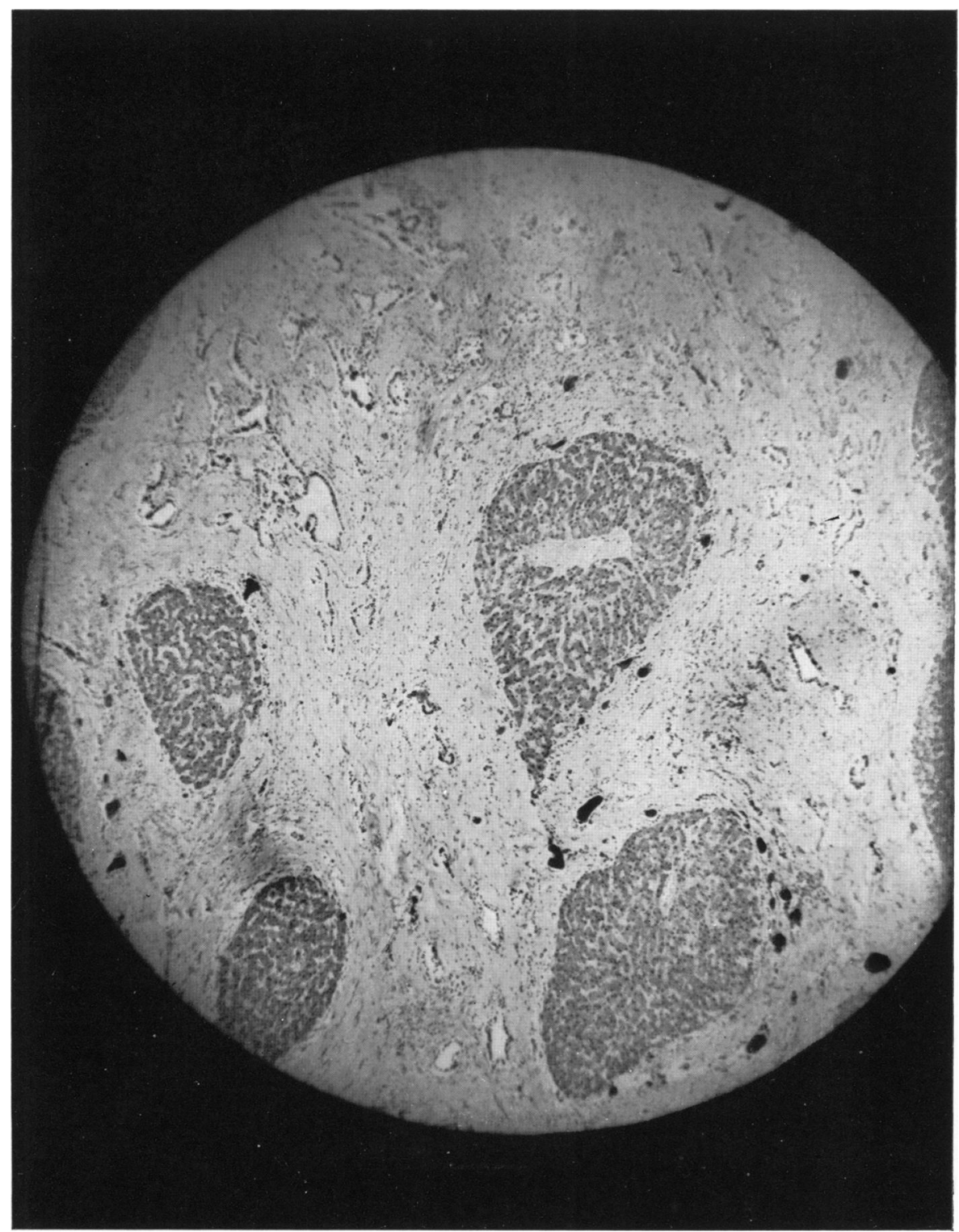

FIG. 6.-Case 4. Liver section. $\quad \times 52$

diameter, embedded in a hard matrix of light grey fibrous tissue. Hepatic veins were visible and were patent, though compressed. Blunt dissection demonstrated the isolated and distorted liver lobules in a thick matrix of firm fibrous tissue. 
Microscopical examination of the liver showed each lobule to be separated from the next by massive interstitial fibrosis. The architecture of the lobules was not deranged, the parenchymal cells appeared normal, and central veins were visible (fig. 6). No normal portal tracts could be seen, and few vessels were visible, but isolated small arteries were present and compressed veins of various sizes were seen. There were some pseudo bile canaliculi, and also some canaliculi lined by a thin layer of flat epithelium and distended by orangecoloured bile. The fibrous tissue was dense, and there was slight lymphocytic infiltration near the borders of the lobules, but the whole was unlike the picture of degeneration, inflammation and regeneration in the first three cases.

The classification of such a case offers difficulties ; it has been pointed out that unilobular hypertrophic cirrhosis is not identical with biliary cirrhosis, and there were no obvious catarrhal changes in the canaliculi here. Clinically the course was that of portal cirrhosis, and pathologically the portal veins were seen to be compressed. It seems reasonable to describe the condition as portal cirrhosis of unilobular distribution without nodular hyperplasia. Interstitial hepatic fibrosis would be a simpler name.

Another type of liver disease that is occasionally mentioned is the 'cirrhosis' of icterus gravis neonatorum (Poynton and Wyllie, 1926). Hawksley and Lightwood (1934) found a fine perilobular fibrosis in the livers of children who survived icterus gravis for from five weeks to ten months. There were no clinical signs of cirrhosis, although signs of biliary obstruction occur transiently in some cases of icterus gravis. One case which recovered, but died at the age of ten weeks from pertussis, had no fibrosis. Pfannenstiel (1908) is cited as having described a case which proceeded to cirrhosis, but the diagnosis of icterus gravis, as the disease is defined now, is not certain. Braid (1937) described another case, in which portal cirrhosis with fatal haematemesis supervened at the age of three-and-a-half years. But here again it is permissible to doubt the original diagnosis of icterus gravis. The stools were acholic for an unusually long time (seven weeks). Anaemia, after four weeks of life without treatment, was surprisingly slight. The spleen was not enlarged until the age of five months. Erythroblastosis was not described.

One cannot doubt that a fine fibrosis may develop in the liver in icterus gravis. Such a liver may possibly be left more susceptible to toxins or nutritional disturbances at a later date. But the existence of a special type of clinical cirrhosis associated with or following icterus gravis is very doubtful.

There is also one other definite type of biliary cirrhosis. This is the infantile biliary cirrhosis, of unknown causation, which is common in certain parts of India (Mukherji, 1922). Cases are not seen in Britain, and further reference to it is not necessary here.

\section{Conclusions}

There are at least four well-attested types of biliary cirrhosis :

A. Congenital biliary cirrhosis, with or without congenital obliteration of the bile ducts.

B. The infantile biliary cirrhosis of Indian nurslings. This differs from 
congenital biliary cirrhosis in age incidence, local occurrence, slower course and absence of obliterative cholangitis.

C. Acquired obstructive biliary cirrhosis. The signs and symptoms of this type are those of chronic, usually unremitting, obstruction of the common bile duct, enlargement of the liver and possibly of the spleen, sometimes portal failure and cholaemia. Appropriate tests show impairment of liver function.

D. Acquired non-obstructive biliary cirrhosis (hypertrophic biliary cirrhosis, Hanot's syndrome). This is a rare disease of long duration. It attacks mainly children and young adults. The onset is indistinguishable from catarrhal jaundice, but icterus does not completely disappear after the attack. Vomiting, epigastric pain and pyrexia subside, only to reappear at a later date. The course consists of a substratum of chronic jaundice and at first rather mild ill-health, with exacerbations characterized by abdominal pain, pyrexia, increased jaundice, enlargement of the liver, and vomiting. They recur at intervals of weeks or months, and usually subside in two or three weeks, but leaving the patient in a poorer state than before. The spleen becomes palpable, and in children may be enormous. The liver is at first likely to increase in size with each exacerbation. The stools vary, being usually pale and at times acholic. The urine contains bile salts and pigments. The van den Bergh reaction is biphasic. The blood picture is variable. Anaemia may be macrocytic or microcytic, but is frequently normocytic. There may be no anaemia, and polycythaemia is not unknown. Leucocytosis is common, but leucopenia occurs in a minority of cases. Liver function tests show impairment.

As the patient's condition deteriorates, complications occur-perhaps nephritis or staphylococcal infections, or in children clubbing of the fingers. In children growth is eventually stunted, but in general, anorexia and wasting are surprisingly slight. Every patient is likely to have haemorrhage from some site. The liver becomes gradually smaller. In time, usually years after the onset, massive haematemesis and ascites may develop, and the picture of fluctuating portal failure supervenes on fluctuating biliary failure. At this stage the end is not far off, but the individual may struggle on for a few months or a year, and then die in cholaemia or as result of haematemesis or from intercurrent infection. Pathologically the liver shows a diffuse degenerative hepatitis with fibrosis distributed around and within the lobules; the picture may be much altered by nodular hyperplasia. The tissues are bile-stained, there are many pseudo-bile canaliculi, and the true intrahepatic bile ducts show catarrhal changes and bile plugs. The extrahepatic biliary channels may have some signs of past inflammation, but are free from obstruction.

Thanks are due to Dr. Wilfrid Sheldon for allowing the publication of accounts of these cases.

\section{REFERENCES}

Bennett, T. I., Hunter, D., and Vaughan, J. M. (1932). Quart. J. Med., 1, 603.

Braid, F. (1937). Arch. Dis. Childh., 12, 389.

Braithwaite, J. V. (1934). Proc. roy. Soc. Med., 27, 1008. 
Broadbent, J. F. H. (1905). Trans. path. Soc. Lond., 56, 143.

Chiroy, M., Albot, G., and Malinsky, A. (1935). Bull. Mém. Soc. méd. Hôp. Paris, 59, 907. Chisholm, R. A. (1914). Brit. J. Child. Dis., 11, 397.

Crooks, J. C. (1925). Lancet, 1, 273.

Ellis, R. W. B. (1938). Proc. roy. Soc. Med., 31, 1048.

Evans, P. R. (1934). Ibid., 28, 154.

- (1937a). Ibid., 30, 406.

- (1937b). Loc. cit., 878.

Fiessinger, N., Olivier, H-R., and Albot, G. (1929). Bull. Mém. Soc. méd. Hôp. Paris, 53, 1318.

Flint, E. R. (1937). Brit. med. J., 2, 253.

Ford, W. F. (1901). Amer. J. med. Sci., 121, 60.

Gilbert, A., and Lereboullet, M. P. (1900). Bull. Mém. Soc. Méd., Paris, 17, 490.

—_, -

_- _- (1895b). Rev. mens. Mal. Enf., 13, 309.

-_, _- (1897). C. R. Soc. Biol., Paris, 49, 692.

Gordon, K. (1922). Boston med. and surg. J., 187, 92.

Hanot, V. (1876). Étude sur une forme de cirrhose hypertrophique du foie, Paris.

- and Meunier, H. (1895). C. R. Soc. Biol., Paris, 47, 49.

Hawksley, J. C., and Lightwood, R. (1934). Quart. J. Med., 3, 155.

Hayem, G. (1874). Arch. Physiol. norm. path., 1, 126.

Holmes, J. B. (1916). Amer. J. Dis. Child., 11, 405.

Hutchison, R. (1936). Lectures on Diseases of Children, London, 375.

Jewesbury, R. C. (1936). Proc. roy. Soc. Med., 29, 737.

(1937). Ibid., 31, 75.

Judd, E. S., Snell, A. M., and Hoerner, M. J. (1935). J. Amer. med. Ass., 105, 1653.

Keys, A., and Snell, A. M. (1938). J. clin. Invest., 17, 59.

Ladd, W. E. (1935). Ann. Surg., 102, 742.

Lange, C. (1922). Klin. Wschr., 1, 1040.

Lereboullet, P. (1901). Bull. Soc. de Pédiat., Paris, 3, 89.

Locke, E. A. (1915). Arch. intern. Med., 15, 659.

Milne, L. S. (1912). Quart. J. Med., 5, 409.

Mukherji, S. K. (1922). Infantile Cirrhosis of the Liver, Calcutta.

Munns, G. E. (1926). Amer. J. Dis. Child., 31, 459.

Newns, G. H. (1935). Proc. roy. Soc. Med., 28, 761.

Nobécourt, P., and Babonneix, L. (1934). Traité de Médecine des Enfants, Paris, 4, 117.

Parsons, L. G., and Hickmans, E. M. (1926). Amer. J. Dis. Child., 31, 459.

Pfannenstiel, J. (1908). Münch. med. Wschr., 55, 2169.

Phillips, F. A. (1937). Lancet, 1, 1050.

Poynton, F. J., and Wyllie, W. G. (1926). Arch. Dis. Childh., 1, 1.

Rich, A. R. (1930). Johns Hopk. Hosp. Bull., 47, 338.

Rolleston, H. D. (1907). Brit. med. J., 2, 947.

— and Wyard, S. (1920). Ibid., 2, 544.

- and McNee, J. W. (1929). Diseases of the Liver, Gall Bladder, and Bile Ducts, London.

Rous, P., and Larimore, L. D. (1920). J. exp. Med., 33, 249.

Smith, H. R. (1898). Trans. clin. Soc. Lond., 31, 258.

Snell, A. M. (1938). Proc. Mayo Clin., 13, 65.

Strauss, A. A., Strauss, S. F., Crawford, R. A., and Strauss, H. A. (1933). J. Amer. med. Ass., 101, 1065.

Taylor, F. (1895). Guy's Hosp. Rep., 52, 45. (1897). Ibid., 54, 1.

Todd, R. B. (1857). Med. Times Gaz., Lond., 15, 571.

Weber, F. P. (1934). Proc. roy. Soc. Med., 27, 1010.

Wyllie, W. G. (1925). Lancet, 1, 273. 